\title{
Heat, volume and chemical fluxes from submarine venting: A synthesis of results from the Rainbow hydrothermal field, $36^{\circ} \mathrm{N}$ MAR
}

\author{
C.R. German ${ }^{a}{ }^{,}$, A.M. Thurnherr ${ }^{b}$, J. Knoery ${ }^{c}$, J.-L. Charlou ${ }^{d}$, P. Jean-Baptiste ${ }^{e}$ and H.N. Edmonds ${ }^{\dagger}$
}

\author{
${ }^{a}$ MS\#24, Woods Hole Oceanographic Institution, Woods Hole MA 02543, USA \\ ${ }^{\mathrm{b}}$ Lamont Doherty Earth Observatory, Palisades NY 10964, USA \\ c IFREMER département BE, centre de Nantes, 44311 Nantes, France \\ d IFREMER département GM, centre de Brest, 29280 Plouzane, France \\ e CEA-CNRS, LSCE, CEA-Saclay, 91191 Gif-sur-Yvette, France \\ ${ }^{\mathrm{f}}$ The University of Texas at Austin, Marine Science Institute, Port Aransas, TX 78373 \\ *: Corresponding author : C.R. German, Tel.: +1 508289 2853; fax: +1 508457 2150, email address : \\ cgerman@whoi.edu
}

\begin{abstract}
:
High-temperature hydrothermal activity occurs in all ocean basins and along ridge crests of all spreading rates. While it has long been recognized that the fluxes associated with such venting are large, precise quantification of their impact on ocean biogeochemistry has proved elusive. Here, we report a comprehensive study of heat, fluid and chemical fluxes from a single submarine hydrothermal field. To achieve this, we have exploited the integrating nature of the non-buoyant plume dispersing above the Rainbow hydrothermal field, a long-lived and tectonically hosted high-temperature vent site on the Mid-Atlantic Ridge. Our calculations yield heat and volume fluxes for high-temperature fluids exiting the seafloor of $\approx 0.5 \mathrm{GW}$ and $450 \mathrm{~L} \mathrm{~s}^{-1}$, together with accompanying chemical fluxes, for Fe, $\mathrm{Mn}$ and $\mathrm{CH}_{4}$ of $\approx 10, \approx 1$ and $\approx 1 \mathrm{~mol} \mathrm{~s}^{-1}$, respectively. Accompanying fluxes for 25 additional chemical species that are associated with Fe-rich plume particles have also been calculated as they are transported away from the Rainbow vent site before settling to the seabed. High-temperature venting has been found to recur at least once every $\sim 100 \mathrm{~km}$ along all slow-spreading ridges investigated to-date, with half of all known sites on the Mid-Atlantic Ridge occurring as long-lived and tectonically hosted systems. If these patterns persist along all slow- and ultraslow-spreading ridges, high-temperature venting of the kind reported here could account for $\sim 50 \%$ of the on-axis hydrothermal heat flux along $\approx 30,000 \mathrm{~km}$ of the $\approx 55,000 \mathrm{~km}$ global ridge crest.
\end{abstract}

Keywords: Hydrothermal fluxes; Biogeochemistry; Rainbow vent-field 


\section{Introduction}

Hydrothermal venting has long been recognized to provide significant fluxes of both heat and chemicals to the deep ocean (Edmond et al., 1979; Elderfield \& Schultz, 1996). While numerous efforts have been made to quantify the heat flux associated with ridge-crest hydrothermal activity, however, less satisfactory progress has been achieved in determining the associated chemical fluxes - largely because of uncertainties that persist in the partitioning of axial heat-flux between hot "black smoker" fluids and lower temperature diffuse emissions (Schultz \& Elderfield, 1997; Veirs et al., 2006). This differentiation is non-trivial because it is only at high temperatures that many species are released from submarine venting to the oceans (German \& Von Damm, 2004). Thus, while consensus may be approached among studies that use conservative tracers to calculate the volume of fluid that is heated to high temperatures along the global ridgeaxis, annually (Chan et al., 2002; Teagle et al., 2003; Nielsen et al., 2006), what remains elusive is any clear understanding of the associated flux of biogeochemically active species released to the overlying water column.

With the recent demonstration that high-temperature venting occurs along all mid-ocean ridges, at all spreading-rates and, hence, in all ocean basins (Baker \& German, 2004) a better understanding of the size and the distribution of these detailed biogeochemical fluxes is required. For example, recent studies have shown that hydrothermally-sourced $\mathrm{Fe}$, one of the most abundant elements present in end-member vent-fluids, may contribute significantly to global deep-ocean dissolved Fe budgets (Chu et al., 2006; Bennett et al., 2008) and may play an important role in biogeochemical cycles at both local and global scales (Coale at al., 1996; Mackey et al, 2002; Toner et al., in press). To address this issue, therefore, we have combined an interdisciplinary study of the physics and geochemistry of the Rainbow hydrothermal plume near $36^{\circ} \mathrm{N}$ on the Mid-Atlantic Ridge, together with studies of end-member vent-fluids at the seafloor, to calculate the first integrated fluxes of heat and chemicals exported from a single ventfield to the overlying ocean. While it may not be appropriate to extrapolate this first study to the global scale, our approach is important because it provides a template by which future studies at different vent-sites, elsewhere along the global ridge-crest could be conducted as well as providing a novel context from which prior global-scale estimates can be re-examined.

\section{Background}

The Rainbow hydrothermal field is located at $36^{\circ} 14^{\prime} \mathrm{N}$ on the Mid-Atlantic Ridge (Fig.1) and comprises ten discrete high temperature $\left(-365^{\circ} \mathrm{C}\right)$ vents (Fouquet et al., 1998). The site was first identified from combined deep-tow sidescan/optical backscatter sensor investigations followed by detailed CTD and tow-yo investigations (German et al., 2006 a,b). Field-work for this project was conducted in 1997 and 1998 using a combination of surface ship and deep-diving submersible Nautile operations. First, a detailed water-column investigation was conducted that located the source of venting to within $<1 \mathrm{~km}$, constrained the nature and direction of non-buoyant plume dispersion, carried out extensive sampling of the plume for shipboard and shorebased geochemical investigation, and deployed a series of long-term current meter moorings (German et al., 1997). This was followed by a series of 10 Nautile dives that located and sampled individual vent-sites at the seafloor after which a pair of long-term sediment trap 
moorings designed to intercept the non-buoyant plume were deployed (Fouquet et al., 1997). Recovery of both current meter and sediment trap moorings was completed approximately 12 months later (German et al., 1998a). Previously we have reported on the composition of end-member vent-fluids at Rainbow (Douville et al., 2002; Charlou et al., 2002), the physical dispersion of the overlying plume (Thurnherr \& Richards, 2001; Thurnherr et al., 2002) and the chemical composition of that plume's dissolved and particulate constituents (Jean-Baptiste et al., 2004; Edmonds \& German, 2004). What is particularly unique to this contribution, however, is the synthesis of integrated heat and chemical export fluxes that can now be calculated. No comparable study of the combined export fluxes from any single vent-site to the ocean has ever been reported.

\section{Flux Calculations}

\subsection{Overview and optical-sensor based fluxes}

To obtain representative fluxes of heat and chemicals from the Rainbow hydrothermal vent-field we have adopted a novel approach that takes advantage of the integrating nature of its overlying hydrothermal plume. When buoyant hydrothermal fluids rise from the seafloor they mix turbulently, entraining ambient seawater ( \pm effluents from nearby diffuse sources), until a level of neutral buoyancy is attained (Lupton, 1995). At Rainbow, a coherent non-buoyant plume is formed $\sim 200 \mathrm{~m}$ above the seafloor that is advected to the NE, crossing a sill at $\sim 36^{\circ} 16-17^{\prime} \mathrm{N}, 33^{\circ} 53-54^{\prime} \mathrm{W}, \sim 4 \mathrm{~km}$ downstream from the vent-field (German et al., 1998b). It is by investigating the transport of hydrothermal plume material across this sill that we have been able to determine the heat and chemical export fluxes from the Rainbow vent-site to the ocean.

Current velocities across the Rainbow sill have been determined from both shortterm (LADCP/CTD) and long-term (current-meter mooring) measurements (Thurnherr \& Richards, 2001; Thurnherr et al., 2002). Here, we combine that physical flow information (Fig.2a) with in situ optical back-scatter data which provides a particularly sensitive technique for investigating particle-laden hydrothermal plumes in the deep-ocean, away from continental/detrital run-off or other sources of suspended particulate load (Baker et al., 1995). At Rainbow, a SeaTech Light Scattering Sensor (LSS) was fitted to the BRIDGET deep-tow vehicle to conduct detailed 3-D plume investigations (German et al., 1998a,b). An integrated Gaussian fit has subsequently been applied to near-field LSS voltage-anomalies (with respect to the water column above the particle plume) that were recorded close to Rainbow sill during the at-sea program (Fig. 2b). When combined with the LADCP-derived near-field velocity profile and an estimate of plume-width (Thurnherr and Richards, 2001), this yields a total "plume-particle flux" across Rainbow sill of $9000 \mathrm{~V} \cdot \mathrm{m}^{3} \cdot \mathrm{s}^{-1}$. The greatest uncertainty in this calculation lies in the determination of the cross-sectional width of the plume which we estimate to be accurate to within a factor of 2 (Thurnherr \& Richards, 2001). It is this measure that dominates all other uncertainties in the flux calculations that follow. Figure $2 \mathrm{c}$ shows that optical backscatter anomalies are highly correlated with mid-water temperature anomalies in the Rainbow plume, indicating that LSS voltage-anomalies are directly proportional to the extent of dilution of high-temperature vent-fluid by entrained background water. This is important because it is these same optical backscatter anomalies, when correlated with geochemical anomalies, that we use to calculate both thermal and geochemical export fluxes from the Rainbow hydrothermal field. 


\subsection{Dissolved tracer fluxes}

During our plume-survey studies, discrete water samples were collected throughout the Rainbow plume. Because of the small-volume (1.7L) bottles available on the BRIDGET vehicle (Rudnicki et al., 1995), only samples for total dissolvable Mn (TDMn) and dissolved $\mathrm{CH}_{4}$ analysis were collected during our 3-D survey of in situ optical backscatter distributions (German et al., 1998b). In addition, however, samples for TDMn, TDFe, dissolved $\mathrm{CH}_{4}$ and dissolved ${ }^{3} \mathrm{He} /{ }^{4} \mathrm{He}$ analyses were collected from a series of vertical CTD-rosette casts using 30L Niskin bottles (Jean-Baptsite et al., 2004).

Both dissolved $\mathrm{CH}_{4}$ and TDMn measured in the large-volume CTD-rosette samples show strong positive linear correlations with dissolved ${ }^{3} \mathrm{He}$ concentrations (Fig.3), as well as with each other (Fig. 4). This is significant because dissolved ${ }^{3} \mathrm{He}$ behaves as an entirely conservative tracer in dispersing hydrothermal plumes. Consequently, the constant $\mathrm{CH}_{4}:{ }^{3} \mathrm{He}$ and TDMn: ${ }^{3} \mathrm{He}$ ratios observed for the Rainbow plume provide clear evidence that dissolved $\mathrm{CH}_{4}$ and TDMn also behave conservatively (Fig.3). Further, because both dissolved $\mathrm{CH}_{4}$ and TDMn data from samples collected from the BRIDGET deep-tow vehicle also correlate closely with co-registered LSS voltage-anomalies (Fig.5), we can infer that the latter tracer, for which we have the most complete 3-D data-set, also behaves conservatively over the time-scale taken (estimated at 4-20 days; German et al., 1998b, Jean-Baptiste et al., 2004) for the dispersing plume to be transported as far as, and across, the Rainbow sill. Finally, because the $\mathrm{CH}_{4}:{ }^{3} \mathrm{He}$ and TDMn: ${ }^{3} \mathrm{He}$ ratios reported here are indistinguishable from those for the end-member vent-fluids at Rainbow (Jean-Baptiste et al., 2004), the export fluxes we calculate for these tracers across the Rainbow sill must also represent their gross fluxes from the source vent-site, with no intervening loss, whether through oxidation, precipitation or biological uptake.

Using the close linear relationships observed with in situ optical back-scatter data (Fig. 5; Appendix), we can calculate fluxes for dissolved $\mathrm{CH}_{4}$ and TDMn. For a plume particle flux of $9000 \mathrm{~V} \cdot \mathrm{m}^{3} . \mathrm{s}^{-1}$ these correspond to chemical export fluxes of $1.0 \mathrm{~mol} . \mathrm{s}^{-1}$ for $\mathrm{CH}_{4}$ and $0.9 \mathrm{~mol}^{-1}{ }^{-1}$ for TDMn from the Rainbow hydrothermal field (Table 1). Using the $\mathrm{CH}_{4}:{ }^{3} \mathrm{He}$ correlation determined for the non-buoyant hydrothermal plume (Fig.3; Appendix) the corresponding ${ }^{3} \mathrm{He}$ export flux is calculated as $7.6 \mathrm{nmol} . \mathrm{s}^{-1}$ (Table 1 ).

\subsection{Volume and heat fluxes from high-temperature fluids exiting the seafloor at Rainbow.}

If we combine the chemical export fluxes calculated for $\mathrm{CH}_{4}$ and TDMn in the non-buoyant plume, together with known end-member compositions for vent-fluids at Rainbow, we can now calculate the integrated fluxes of heat and mass transported in the form of high-temperature vent-fluids exiting the seafloor across the entire Rainbow hydrothermal field. This is a measure that has not previously been achieved for any seafloor hydrothermal system. The flux of $365^{\circ} \mathrm{C}$ fluid required to sustain a plume export flux of $1.0 \mathrm{~mol} / \mathrm{s}^{-1}$ dissolved $\mathrm{CH}_{4}$, assuming an end-member fluid concentration of

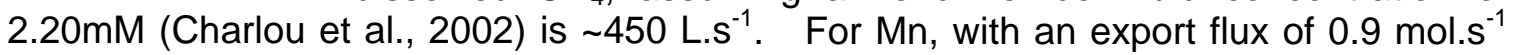
and end-member vent fluid concentrations of $2.25 \mathrm{mM}$ (Douville et al., 2002) the calculated volume-flux is identical, within error, at $\sim 400 \mathrm{~L}^{-1} \mathrm{~s}^{-1}$ (Table 1). Note that this integrated measure captures the entire volume flux for high-temperature fluids exiting the multiple high-temperature vents that are active across the entire Rainbow hydrothermal field. For individual chimneys, average fluxes would be some tens of litres per second. 
In addition to using chemical tracer data to determine vent-fluid volume fluxes, we can also use the same approach to calculate heat fluxes from Rainbow. If we combine our calculated ${ }^{3} \mathrm{He}$ flux of $7.6 \times 10^{-9} \mathrm{~mol}^{-1} \mathrm{~s}^{-1}$ with the ${ }^{3} \mathrm{He}$ :heat ratio for Rainbow vent-fluids, we can calculate a corresponding integrated heat flux from the Rainbow hydrothermal field. Previously, Jean-Baptiste et al. (2004) have reported a source-fluid helium:heat ratio of $9.3( \pm 2.0) \times 10^{-18}$ mol. $\mathrm{J}^{-1}$. This source-fluid helium:heat ratio was calculated using the equation:

$$
\text { helium/heat }={ }^{3} \mathrm{He} /\left(\mathrm{c}_{\mathrm{p}} \cdot \Delta \theta_{i}\right)
$$

with mean values for Rainbow of ${ }^{3} \mathrm{He} \sim 25 \times 10^{-12}$ mol. $\mathrm{kg}^{-1}$ and $\Delta \theta_{i}$ (source temperature anomaly) $-365^{\circ} \mathrm{C}$ together with a specific heat value of $c_{p} \sim 7.4 \times 10^{3}$ $\mathrm{J} . \mathrm{kg}^{-1} \cdot \mathrm{K}^{-1}$. However, according to Appendix 5 of Bischoff and Rosenbauer (1985), that is only the appropriate value for $c_{p}$ when estimating how much heat is required to heat seawater that is already at $360^{\circ} \mathrm{C}$ by a further $1^{\circ} \mathrm{C}$. In order to heat seawater from ambient deep-ocean temperatures $\left(\sim 2^{\circ} \mathrm{C}\right)$ to $360^{\circ} \mathrm{C}$ it is more appropriate to apply a temperature-averaged $c_{p}$ value for the specific heat. By averaging values for $c p$ at $2000 \mathrm{~m}$ water depth, between $0^{\circ} \mathrm{C}$ and $360^{\circ} \mathrm{C}$, using high-temperature values taken from Bischoff and Rosenbauer (1985), we now calculate a more appropriate value for the Rainbow system of

$\mathrm{C}_{\mathrm{p}} \sim 4.6 \times 10^{3} \mathrm{~J} \cdot \mathrm{kg}^{-1} \cdot \mathrm{K}^{-1}$. If this corrected value of $\mathrm{c}_{\mathrm{p}}$ is now substituted into equation (i), above, a revised, higher, helium:heat ratio is obtained of $\sim 1.5 \times 10^{-17}$ mol. $J^{-1}$. Combining that helium:heat ratio with the calculated 3He export flux of $7.6 \mathrm{x}$ 10-9 mol.s-1 results in a revised heat-flux estimate for the Rainbow vent-field of $\sim 0.5 \mathrm{GW}$.

It is important to note that this heat-flux estimate is lower than, and lies outside of, the 1-5GW range of probable values calculated previously by Thurnherr and Richards (2001), even though both estimates are based on the same "plume-particle flux" of $9000 \mathrm{~V} . \mathrm{m}^{3} \cdot \mathrm{s}^{-1}$. Primarily, this is due to a difference in the way in which the particle flux has been applied to calculate the heat flux. Here, we have used correlations between light scattering sensor data, $\mathrm{CH}_{4}$ and ${ }^{3} \mathrm{He}$ measurements in the non-buoyant plume, and the source vent-fluid ${ }^{3} \mathrm{He}$ :heat ratio. In contrast, the estimate used by Thurnherr and Richards (2001) pre-dated acquisition of the necessary geochemical data and, instead, used a much less direct approach, involving a model to relate temperature anomalies recorded at plume-height to source-fluid temperature anomalies. It appears plausible that the approximations implicit in some of the model's simplifying assumptions, such as a linear background T/S relationship and constant source-fluid properties, can cause a bias in the estimate of this relationship.

Of course, it should also be noted that the estimate derived here can only be considered accurate if the source-fluid ${ }^{3} \mathrm{He}$ :heat ratio derived from the data of JeanBaptiste et al. (2004) from samples collected by submersible is appropriate to be applied to the plume samples collected approximately one month earlier during the detailed hydrothermal plume survey. Given the apparent constancy of fluid compositions at Rainbow over decadal timescales, 1997-2008 (J.Seewald, T.McCollom \& C.German, unpubl. data), however, it would appear unlikely that temporal variability in the ${ }^{3} \mathrm{He}$ :heat ratio of the source vent-fluids, over much shorter time-scales, is a major source of uncertainty in the $\sim 0.5 \mathrm{GW}$ heat-flux for the Rainbow hydrothermal field that has been calculated here. 


\subsection{Calculation of Fe fluxes}

While various dissolved tracers may behave quasi-conservatively in hydrothermal plumes, dissolved Fe typically does not. Instead, it tends to precipitate rapidly within buoyant hydrothermal plumes to form a mixture of sulfide and oxyhydroxide phases. Typically, it is estimated that some $50 \%$ of dissolved Fe released from vents might be precipitated nearly instantaneously as polymetallic sulfides (Rudnicki \& Elderfield, 1993). At Rainbow, however, the vent-fluid $\mathrm{Fe}: \mathrm{H}_{2} \mathrm{~S}$ ratio has an exceptionally high value of 24:1 (Douville et al., 2002). Consequently, quantitative coprecipitation with sulfide as $\mathrm{Fe}(\mathrm{II}) \mathrm{S}$ could not account for removal of more than $\sim 4 \%$ of the total Fe inventory (Edmonds and German, 2004). Further, because of the rapid oxidation of dissolved Fe(II) in North Atlantic deep-waters, the remaining dissolved $\mathrm{Fe}(\mathrm{II})$ present should all precipitate to form insoluble $\mathrm{Fe}(\mathrm{III})$ oxyhydroxide phases during plume-rise prior to emplacement at non-buoyant plume-height (Field \& Sherrell, 2000). In good agreement with this, the trend for TDFe vs. TDMn in the Rainbow plume (Fig.6) exhibits an overall Fe:Mn ratio of 10.4:1 which is almost identical to the end-member ratio of 10.7:1 for Rainbow vent-fluids (Douville et al., 2002). The significance of this trend is two-fold: first, from an intercomparison of vent-fluid and plume ratios, we can calculate that there has been no more than $\sim 3 \%$ loss of TDFe between venting at the seafloor and emplacement at non-buoyant plume-height, closely coincident with a maximum of $\sim 4 \%$ loss that could be attributed to settling out of dense sulfide material from the buoyant hydrothermal plume. Second, the strong correlation between the two metals' concentrations suggests that Fe, like $\mathrm{Mn}$, also behaves conservatively in the dispersing non-buoyant plume, at least as far as Rainbow sill, despite being present in suspended particulate form. This is entirely consistent with what has already been identified from the close correlation between both TDMn and dissolved $\mathrm{CH}_{4}$ concentrations with in situ optical back-scatter data (Fig.5) and likely results from an interplay of the low density, hence slow settling rates, of Fe-oxyhydroxide precipitates in the deep ocean and the unusually strong currents (order $10 \mathrm{~cm} . \mathrm{s}^{-1}$ ) present in the Rainbow non-buoyant plume (Fig.2a). From the TDFe:TDMn ratio calculated for our plume samples (Fig.6), coupled with the previously calculated Mn flux, we calculate a hydrothermal export flux of Fe from the Rainbow hydrothermal field of $9.6 \mathrm{~mol}^{\mathrm{sec}} \mathrm{s}^{-1}$ (Table 1).

\subsection{Calculation of other particle-associated geochemical fluxes}

Within the Rainbow hydrothermal plume, as in all other high-temperature systems investigated to-date, Fe oxidation and precipitation leads to the uptake, through co-precipitation and/or scavenging, of a range of additional trace elements (Edmonds \& German, 2004). Although there are significant differences between the behaviours of different groups of metals with respect to $\mathrm{Fe}$ in hydrothermal plumes (German \& Von Damm, 2004) a common factor is that all show some form of positive correlation with particulate Fe concentrations. By combining our calculated Fe export flux of $9.6 \mathrm{~mol} . \mathrm{s}^{-1}$ with the positive correlations obtained from detailed chemical analyses of filtered particulate plume samples (Appendix), we are able to calculate export fluxes from the Rainbow hydrothermal-field for a further 24 elements. Note that those particulate-metal export fluxes (Table 1) are grouped according to behaviour type within the non-buoyant plume: "chalcophile", "oxyanion" and "scavenged" (Edmonds \& German, 2004). 
For the "scavenged" group ( $Y+R E E)$ these fluxes largely represent fluxes of metals that have been adsorbed from seawater within the young non-buoyant plume, rather than metals supplied by the vent-fluids (German et al., 1990). Further, the fluxes reported here across Rainbow Sill will likely under-represent the total removal flux for those elements associated with the Rainbow plume, because continuing adsorption onto the Fe particles is to be expected, both as they continue to disperse through the water column and after settling to the seafloor (German et al., 1990; Olivarez \& Owen, 1989).

\section{Discussion}

\subsection{Partitioning of fluxes at Rainbow: focused vs diffuse flow}

The fluxes reported here represent the most comprehensive record, to date, of heat and chemical fluxes from an individual deep-sea hydrothermal field. But what is the broader significance of the work? When calculating fluxes based upon a water-column survey of a non-buoyant plume, a particularly important question concerns to what extent those fluxes represent material emitted from high-temperature hydrothermal vents or, alternately, from effluents entrained from adjacent diffuse sources (Ginster et al., 1994). This is important because in prior syntheses (Elderfield \& Schultz, 1996; Schultz \& Elderfield, 1997) it had been estimated that only $\sim 10 \%$ of the hydrothermal heat-flux released from mid-ocean ridge axes might be present in the form of chemically-laden high-temperature fluid flow. By contrast, Veirs et al. (2006) have suggested that hightemperature fluids may be responsible for closer to $50 \%$ of the total axial hydrothermal heat-flux while Nielsen et al. (2006) report that high temperature hydrothermal fluids may extract $5-80 \%$ of the available magmatic heat-flux (best estimate $\sim 20 \%$ ).

At Rainbow, high-temperature venting is located in a northward-flowing boundary current with a root mean square speed, recorded by a current-meter close to the vent field at $2300 \mathrm{~m}$ depth, of $5.5 \mathrm{~cm} / \mathrm{s}$. This is consistent with the observation that all instantaneous velocities measured with an LADCP during our survey exceeded $5 \mathrm{~cm} / \mathrm{s}$ (Fig. 2a). Substituting values appropriate for the Rainbow vents into Speer \& Rona (1989)'s buoyant-plume model, we calculate that the entrainment velocity $5 \mathrm{~m}$ from the plume center-line should remain below $5 \mathrm{~cm} / \mathrm{s}$ throughout the bottom $50 \mathrm{~m}$ of the water column, i.e. any effluent released from diffuse-flow hydrothermal sources located more than a few meters away from any Rainbow high-temperature vent would not be expected to be entrained into the resulting buoyant hydrothermal plumes.

This physical oceanographic prediction is entirely consistent with our geochemical results from Rainbow. Of course, for conservative tracers such as ${ }^{3} \mathrm{He}$ the total flux exported through the non-buoyant plume could equally result from injection as undiluted end-member $365^{\circ} \mathrm{C}$ vent-fluid emitted at the seafloor or as entrained diffuse flow following subsurface dilution of hot vent-fluids, subsurface. The same argument also applies for our calculated $\mathrm{Mn}$ and $\mathrm{CH}_{4}$ fluxes because both tracers can pass through the dilution and cooling associated with diffuse hydrothermal flow without undergoing significant removal from solution (James \& Elderfield, 1996). Dissolved Fe in hydrothermal fluids, by contrast, reacts rapidly during cooling and dilution. Any significant entrainment of "diffuse-flow" into the Rainbow plume, therefore, would be expected to have greatly reduced the observed plume-height Fe:Mn, Fe: $\mathrm{CH}_{4}$ and $\mathrm{Fe}:{ }^{3} \mathrm{He}$ ratios below the source end-member vent-fluid values. The fact that this is not observed provides strong evidence that the fluxes we present here (Table 1) do not include any significant proportion of entrained diffuse-flow but, rather, represent the thermal and 
chemical export flux from a high-temperature submarine hydrothermal field that is discharging $\sim 450 \mathrm{~L} . \mathrm{S}^{-1}$ of $365^{\circ} \mathrm{C}$ vent-fluids via the Rainbow non-buoyant plume.

A question that immediately arises, therefore, is: is there some additional, significant, diffuse-flow flux at Rainbow that is not entrained into the dispersing nonbuoyant plume and, hence, has eluded detection? We consider this unlikely. Comparing sedimentation fluxes at Rainbow over the 12 months of sediment trap deployments for 1997-98 (Khripounoff et al., 2001) with the long-term records obtained from box-coring of pelagic sediments at the same locations, there is no evidence for any significant change in the flux of hydrothermal products from the Rainbow vent-site arriving at, and passing beyond, Rainbow sill, throughout the past $\sim 10,000$ years (Cave et al., 2002). Just to sustain the $0.5 \mathrm{GW}$ of heat-flux associated with high-temperature venting at Rainbow over that period would already require all the available steady-state heat-flux for at least $25 \mathrm{~km}$ along-axis, based on the assumption that heat extraction extends all the way to the base of the oceanic crust at $\sim 6 \mathrm{~km}$, yielding a steady-state along-axis energy flux of $\sim 6 \times 10^{18} \mathrm{~J} / \mathrm{km}$ (German \& Lin, 2004). If circulation only penetrated to $\sim 1.2 \mathrm{~km}$ as has been anticipated to be the case, previously, for faster spreading ridges (Nielsen et al., 2006), the axial magmatic heat-flux available would reduce to $\sim 1.2 \times 10^{18} \mathrm{~J} / \mathrm{km}$ and sustaining the high-temperature fluxes at Rainbow would require all such available heat-flux for $>100 \mathrm{~km}$ along-axis which exceeds the typical length of $2^{\text {nd }}$ order ridge-segments along this section of the Mid-Atlantic Ridge (Parson et al., 2000). Geophysically, therefore, we consider it highly unlikely that diffuse-flow heat fluxes could be an order of magnitude greater than, or even comparable to, the heat flux associated with focussed, high-temperature fluid-flow at Rainbow. Rather, hightemperature venting appears to dominate the total heat flux at this site.

\subsection{Comparison of local- and global-scale hydrothermal fluxes.}

While what we report here are the first detailed export fluxes of heat and chemicals from a single submarine hydrothermal field, it is important to remember that Rainbow is almost certainly not representative of all such fields, worldwide. Indeed, it would be highly controversial is such were the case. For example, one recentlypublished best estimate for the global flux of high-temperature hydrothermal fluids (Nielsen et al., 2006) is only $7.2 \times 10^{12} \mathrm{~kg} / \mathrm{yr}$. Given the steady-state volume-flux calculated here this would imply that there should only be $\sim 500$ high-temperature ventsites worldwide if each were comparable in flux to the Rainbow site. Clearly this would be extremely difficult to reconcile with what is already known about global-scale ventdistributions: nearly 300 separate sources of high-temperature venting have already been identified and located yet only $\sim 20 \%$ of the ridge crest has been systematically surveyed to-date (Baker \& German, 2004). Further, the recurrence of volcanic eruptions along the fast-spreading East Pacific Rise, at $9^{\circ} 50^{\prime} \mathrm{N}$, on apparent decadal time scales (Haymon et al., 2002; Tolstoy et al., 2006) preclude the possibility of long-lived and sustained venting such as reported here being the norm, worldwide. To evaluate the impact of high-temperature venting on the biogeochemistry of the deep-ocean overlying fast-spreading ridges, therefore, must await completion of a study, comparable to that reported here, for a fast-spreading ridge hydrothermal vent-site.

What is interesting to consider here, however, is what the implications for hydrothermal fluxes might be if Rainbow-sized hydrothermal systems were to prevail along just slow and ultra-slow spreading ridges where vigorous hydrothermal systems have been reported that host large metalliferous deposits suggestive of long histories of focused high-temperature flow (e.g. TAG, Logachev \& Ashadze on the Mid-Atlantic 
Ridge; $40^{\circ}$ S on the SW Indian Ridge: Humphris \& Cann, 2000; ??; Fouquet et al., 2007; Tao et al., 2007). Cumulatively, ridges that spread at $0-40 \mathrm{~mm} /$ year full-spreading rate comprise $-30,000 \mathrm{~km}$ of the entire $55,000-60,000 \mathrm{~km}$ global ridge crest (Sinha \& Evans, 2004). Further, while medium-fast ridges generate close to $80 \%$ of global ocean crust production, annually, the proportion of associated mass that may be leached by hightemperature fluid flow is only $-0.9 \times 10^{16} \mathrm{~g} / \mathrm{yr}$, assuming fluid circulation only penetrates to the top of an axial magmatic lens (Nielsen et al., 2006). By contrast, at slower-spreading ridges (assuming fluid circulation to the base of the oceanic crust) the corresponding mass flux is $\sim 1.1 \times 10^{16} \mathrm{~g} / \mathrm{yr}$. If the distribution of high-temperature fluid discharged along the global rudge-axis matched directly to the heat available from cooling and crystallization of this material it would imply a total best-estimate high-temperature fluidflux of $\sim 4 \times 10^{12} \mathrm{~kg} / \mathrm{yr}$ along the $-30,000 \mathrm{~km}$ of slow and ultra-slow spreading ridge. In the limit, if all of this flux were sustained by venting from Rainbow-sized $\left(0.5 \mathrm{GW}, 450 \mathrm{l} . \mathrm{s}^{-}\right.$ $\left.{ }^{1}\right)$ systems we would expect 250-300 such sites, at a typical spacing of $100-120 \mathrm{~km}$ along the entire slow-and ultra-slow spreading ridge axis extending from the Gakkel Ridge in the high Arctic, along the entire length of the Mid-Atlantic Ridge and extending into the SW Indian Ocean as far as the Rodriguez Triple Junction. Remarkably, the typical spacing calculated by that approach compares very closely with the typical spacing between adjacent sites that has been reported from the few modern and systematic surveys that have been conducted to date along slow- and ultra-slow spreading ridges, extending from the Gakkel and Knipovich Ridges in the Arctic (Edmonds et al., 2003; Connelly et al., 2007) to the southern Mid-Atlantic Ridge (German et al., 2008; Berndt et al., 2008) and the SW Indian Ridge (German et al., 1998c; Bach et al., 2002). While smaller-scale high-temperature hydrothermal systems have also been located associated with neovolcanic activity along both the northern and southern Mid-Atlantic Ridge, previously (e.g. the Snakepit, Broken Spur, Steinaholl and Turtle Pits vent-sites: Gente et al., 1993; Murton et al., 1994; German et al., 1994, 2008) it will be interesting to monitor to what extent large, long-lived hydrothermal systems dominate axial hightemperature hydrothermal fluxes as exploration of these slow and ultra-slow spreading ridges continues.

\section{Summary}

We have exploited the integrating nature of non-buoyant hydrothermal plumes to determine the first integrated fluxes of heat and chemicals exported from a submarine hydrothermal field anywhere along the global ridge-crest. Our study, conducted at the long-lived and tectonically-hosted Rainbow hydrothermal field on the Mid-Atlantic Ridge, indicates heat and volume fluxes for high-temperature fluids exiting the seafloor of $\sim 0.5 \mathrm{GW}$ and 450L.s-1, respectively. Focussed high-temperature fluid flow appears to dominate over diffuse flow at this site with fluxes of $\mathrm{Fe}, \mathrm{Mn}$ and $\mathrm{CH}_{4}$ crossing a sill $\sim 4 \mathrm{~km}$ downstream from the Rainbow vent-site measuring $\sim 10 \mathrm{~mol} . \mathrm{s}^{-1}, 1 \mathrm{~mol} . \mathrm{s}^{-1}$ and $1 \mathrm{~mol} . \mathrm{s}^{-1}$ respectively. From analysis of correlations between conservative and non-conservative tracers in the Rainbow hydrothermal plume we have been able to calculate fluxes for 25 further chemical species exported to the surrounding ocean from Rainbow. While evaluation of the impact of high-temperature venting on the global-scale budgets of these tracers must await completion of comparable study at volcanically-hosted vents on fast-spreading ridges, our calculations indicate that vent-sites comparable to Rainbow, at a mean spacing of $100-120 \mathrm{~km}$ along axis, could dominate high-temperature fluid flow 
along the $-30,000 \mathrm{~km}$ of slow and ultra-slow spreading ridges that comprise just over half the length of the entire global ridge-crest.

\section{Acknowledgements}

We thank the captains, officers, scientists and crews aboard RRS Discovery cruise 228 and FS Poseidon 240 for their assistance at sea during the implementation of our field program. This work was funded by a research grant from the EC (MAS3-970040 "AMORES") supplemented by ship-time awards from the NERC (UK).

\section{References}

Bach et al., 2002 W. Bach, N.R. Banerjee, H.J.B. Dick and E.T. Baker, Discovery of ancient and active hydrothermal systems along the ultra-slow spreading Southwest Indian Ridge 10-16² E, Geochem. Geophys. Geosys. 3 (2002) 10.1029/2001GC000279.

Bachraty et al., 2009 C. Bachraty, P. Legendre and D. Desbruyeres, Biogeographic relationships among deep-sea hydrothermal vent faunas at global scale, Deep Sea Res. 56 (2009), pp. 1371-1378.

Baker et al., 1993 E.T. Baker, G.J. Massoth, s.L. Walker and R.W. Embley, A method for quantitatively estimating diffuse and discrete hydrothermal discharge, Earth Planet. Sci. Lett. 118 (1993), pp. 235-249.

Baker, 1994 E.T. Baker, A 6-year time series of hydrothermal plumes over the Cleft segment of the Juan de Fuca Ridge, J. Geophys. Res. 99 (1994), pp. 4889-4904. Baker et al., 1995 E.R. Baker, C.R. German and H. Elderfield, Hydrothermal plumes: global distributions and geological inferences, Geophys. Monogr. (AGU) 91 (1995), pp. 47-71.

Baker et al., 1996 E.T. Baker, Y.J. Chen and J. Phipps Morgan, The relationship between near-axis hydrothermal coolingand the spreading-rate of mid-ocean ridges, Earth Planet. Sci. Lett. 142 (1996), pp. 137-145.

Baker and German, 2004 E.T. Baker and C.R. German, On the global distribution of hydrothermal vent systems, Geophys. Monogr. (AGU) 148 (2004), pp. 245-266.

Baker et al., 2004 E.T. Baker, H.N. Edmonds, P.J. Michael, W. Bach, H.J.B. Dick, J.E. Snow, S.L. Walker, N.R. Banerjee and C.H. Langmuir, Hydrothermal venting in magma deserts: the ultraslow-spreading Gakkel and Southwest Indian Ridges, Geochem. Geophy. Geosyst. 7 (2004), p. Q11022.

Baker, 2007 E.T. Baker, Hydrothermal cooling of midocean ridge axes: Do measured and modeled heat fluxes agree?, Earth Planet. Sci. Lett. 263 (2007), pp. 140-150.

Bennett et al., 2008 S.A. Bennett, E.P. Achterberg, D.P. Connelly, P.J. Statham, G.R. Fones and C.R. German, The distribution and stabilization of dissolved Fe in deep-sea hydrothermal plumes, Earth Planet. Sci. Lett. 270 (2008), pp. 157-167.

Bischoff and Rosenbauer, 1985 J.L. Bischoff and R.J. Rosenbauer, An empirical equation of state for hydrothermal seawater (3.2\% NaCl), Am. J. Sci. 285 (1985), pp. 725-763. 
Cannat et al., 1999 M. Cannat, A. Briais, C. Deplus, J. Escartin, J. Georgen, J. Lin, S. Mercouriev, C. Meyzen, M. Muller, G. Pouliquen, A. Rabain and P. da Silva, MidAtlantic Ridge-Azores hotspot interactions: along-axis migration of a hotspot-derived event of enhanced magmatism 10-3 Ma ago, Earth Planet. Sci. Lett. 173 (1999), pp. 257-269.

R.R. Cave, C.R. German, J. Thomson and R.W. Nesbitt, Fluxes to sediments from the Rainbow hydrothermal plume, $36^{\circ} 14^{\prime} \mathrm{N}$ on the MAR, Geochim. Cosmochim. Acta 66 (2002), pp. 1905-1923.

Chan et al., 2002 L.H. Chan, J.C. Alt and D.A.H. Teagle, Lithium and lithium isotope profiles through the upper oceanic crust: a study of seawater-basalt exchange at ODP Sites 504B and 896A, Earth Planet. Sci. Lett. 201 (2002), pp. 187-201.

Charlou et al., 2002 J.L. Charlou, J.P. Donval, Y. Fouquet, P. Jean-Baptiste and N. Holm, Geochemistry of high $\mathrm{H}_{2}$ and $\mathrm{CH}_{4}$ vent fluids issuing from ultramafic rocks at the Rainbow hydrothermal field (36² $\left.14^{\prime} \mathrm{N}, \mathrm{MAR}\right)$, Chem. Geol. 191 (2002), pp. 345-359. Chu et al., 2006 N.-C. Chu, C.M. Johnson, B.L. Beard, C.R. German, R.W. Nesbitt, M. Frank, M. Bohn, P.W. Kubik, A. Usui and I. Graham, Evidence for hydrothermal venting in Fe isotope compositions of the deep Pacific Ocean through time, Earth Planet. Sci. Lett. 245 (2006), pp. 202-217.

Coale et al., 1991 K.H. Coale, C.S. Chin, G.J. Massoth, K.S. Johnson and E.T. Baker, Insitu chemical mapping of dissolved iron and manganese in hydrothermal plumes, Nature 352 (1991), pp. 325-328.

Connelly et al., 2007 D.P. Connelly, C.R. German, M. Asada, K. Okino, A. Egorov, N. Pimenov, G. Cherkashev and K. Tamaki, Hydrothermal Activity on the ultra-slow spreading southern Knipovich ridge, Geochem. Geophys. Geosyst. 8 (2007), p. Q08013 10.1029/2007GC001652.

Cooper, 1999 Cooper, M.J., 1999. Hydrothermal studies at the Mid-Atlantic Ridge (Lucky Strike and Rainbow vent sites). U.Cambridge Ph.D. Thesis, 299pp.

Cuvelier et al., 2009 D. Cuvelier, J. Sarrazin, A. Colaco, J. Copley, D. Desbruyeres, A.G. Glover, P. Tyler and R.S. Santos, Distribution and spatial variation of hydrothermal faunal assemblages at Lucky Strike (Mid-Atlantic Ridge) revealed by high-resolution video image analysis, Deep Sea Res. 56 (2009), pp. 2026-2040.

Desbruyeres et al., 2001 D. Desbruyeres, M. Biscoito, J.C. Caprais, A. Colaco, T. Comtet, P. Crassous, Y. Fouquet, A. Khripounoff, N. Le Bris, K. Olu, R. Riso, P.M. Sarradin, M. Segonzac and A. Vangriesheim, Variations in deep-sea hydrothermal vent communities on the Mid-Atlantic Ridge near the Azores plateau, Deep Sea Res. 48 (2001), pp. 1325-1346.

Douville et al., 2002 E. Douville, J.L. Charlou, E.H. Oelkers, P. Bienvenu, C.F.J. Colon, J.P. Donval, Y. Fouquet, D. Prieur and P. Appriou, The Rainbow vent fluids (36 degrees 14 'N, MAR): the influence of ultramafic rocks and phase separation on trace metal content in Mid-Atlantic Ridge hydrothermal fluids, Chem. Geol. 184 (2002), pp. 37-48. J.M. Edmond, C.I. Measures, R.E. McDuff, L.H. Chan, R. Collier, B. Grant, L.I. Gordon and J.B. Corliss, Ridge crest hydrothermal activity and the balances of the major and minor elements in the ocean: the Galapagos data, Earth Planet. Sci. Lett. 46 (1979), pp. $1-18$.

H.N. Edmonds and C.R. German, Particle geochemistry in the Rainbow hydrothermal plume, Mid-Atlantic Ridge, Geochim. Cosmochim. Acta 68 (2004), pp. 759-772. 
Edmonds et al., 2003 H.N. Edmonds, P.J. Michael, E.T. Baker, D.P. Connelly, J.E. Snow, C.H. Langmuir, H.J.B. Dick, C.R. German and D.W. Graham, Discovery of abundant hydrothermal venting on the ultraslow-spreading Gakkel Ridge in the Arctic Ocean, Nature 421 (2003), pp. 252-256.

Elderfield and Schultz, 1996 H. Elderfield and A. Schultz, Mid-ocean ridge hydrothermal fluxes and the chemical composition of the ocean, Ann. Rev. Earth Planet. Sci. 24 (1996), pp. 191-224.

R.A. Feely, M. Lewison, G.J. Massoth, G. Robertbaldo, J.W. Lavelle, R.H. Byrne, K.L. VonDamm and H.C. Curl, Composition and dissolution of black smoker particulates from active vents on the Juan de Fuca Ridge, J. Geophys. Res. 92 (1987), pp. 1134711363.

M.P. Field and R.M. Sherrell, Dissolved and particulate Fe in a hydrothermal plume at 9 $45^{\prime} \mathrm{N}$, East Pacific Rise: slow Fe(II) oxidation kinetics in Pacific plumes, Geochim. Cosmochim. Acta 64 (2000), pp. 619-628.

Fouquet and et al., 1997 Fouquet, Y. et al., 1997. FLORES Diving Expedition to the Rainbow and Lucky Strike Vent fields. R/V l'Atalante Cruise report, 186pp.

Fouquet et al., 1998 Y. Fouquet, F. Barriga, J.L. Charlou, H. Elderfield, C.R. German, H. Ondréas, L. Parson, J. Radford-Knoery, J. Relvas, A. Ribeiro, A. Schultz, R. Apprioual, P. Cambon, I. Costa, J.P. Donval, E. Douville, J.Y. Landuré, A. Normand, H. Pellé, E. Ponsevera, S. Riches, H. Santana and M. Stephan, FLORES diving cruise with the Nautile near the Azores-First dives on the Rainbow field: hydrothermal seawater/mantle interaction, InterRidge News 7 (1998), pp. 24-28.

Fouquet et al., 2007 Fouquet, Y., Cherkashov, G., Charlou, J., Ondreas, H., Cannat, M., Bortnikov, N., Silantiev, S., Etoubleau, J., Scientific Party of the SERPENTINE Cruise, 2007. Diversity of ultramafic hosted hydrothermal deposits on the Mid-Atlantic Ridge: First submersible studies on Ashadze, Logachev 2 and Krasnov vent fields during the SERPENTINE Cruise. EOS Trans AGU Abstr. T51F-03. Gendron et al., 1994 J.F. Gendron, J.F. Todd, R.A. Feely, E.T. Baker and D.C. Kadko, Excess Rn-222 above the cleft segment of the Juan de Fuca Ridge, J. Geophys. Res. 99 (1994), pp. 5007-5015.

Gente et al., 1991 P. Gente, J.M. Auzende, J.A. Karson, Y. Fouquet and C. Mevel, An example of a recent accretion on the Mid-Atlantic Ridge: the Snake Pit neovolcanic ridge (MARK area $23^{\circ} 22^{\prime} \mathrm{N}$ ), Tectonophysics 190 (1991), pp. 1-29.

GEOTRACES (SCOR Working Group), 2008 GEOTRACES (SCOR Working Group), An international study of the global marine biogeochemical cycles of Trace Elements and their Isotopes, Chemie der Erde 67 (2008), pp. 85-131.

German et al., 1990 C.R. German, G.P. Klinkhammer, J.M. Edmond, A. Mitra and H. Elderfield, Hydrothermal scavenging of rare earth elements in the ocean, Nature 345 (1990), pp. 516-518.

German et al., 1991a C.R. German, A.P. Fleer, M.P. Bacon and J.M. Edmond, Hydrothermal scavenging at the Mid-Atlantic Ridge: Radionuclide distributions, Earth Planet. Sci. Lett. 105 (1991), pp. 170-181.

German et al., 1991b C.R. German, A.C. Campbell and J.M. Edmond, Hydrothermal scavenging at the Mid-Atlantic Ridge: Modification of Trace Element Dissolved Fluxes, Earth Planet. Sci. Lett. 107 (1991), pp. 101-114. 
German et al., 1994 C.R. German, J. Briem, C. Chin, M. Danielsen, S. Holland, R. James, A. Jónsdottir, E. Ludford, C. Moser, J. Ólafsson, M.R. Palmer and M.D. Rudnicki, Hydrothermal activity on the Reykjanes Ridge: the Steinahóll vent field at $63^{\circ} 06^{\prime} \mathrm{N}$, Earth Planet. Sci. Lett. 121 (1994), pp. 647-654.

German et al., 1996a C.R. German, L.M. Parson and HEAT Scientific Team, Hydrothermal exploration near the Azores Triple Junction: tectonic control of venting at slow spreading ridges, Earth Planet, Sci. Lett. 138 (1996), pp. 93-104.

German et al., 1996b C.R. German, G.P. Klinkhammer and M.D. Rudnicki, The Rainbow hydrothermal plume, 36¹5'N, MAR, Geophys. Res. Lett. 23 (1996), pp. 2979-2982. German and et al., 1997 German, C.R., et al., 1997. RRS Discovery Cruise D228. FLAME: The Fluxes at AMAR Experiment. SOC Cruise Report No. 10, 96pp. German and et al., 1998a German, C.R., et al., 1998a. FS Poseidon Cruise 240. The Fluxes at AMAR Experiment: FLAME 2. SOC Cruise Report No.20, 44pp. German et al., 1998b C.R. German, K.J. Richards, M.D. Rudnicki, M.M. Lam, J.L. Charlou and FLAME Scientific Party, Topographic control of a dispersing hydrothermal plume, Earth Planet. Sci. Lett. 156 (1998), pp. 267-273.

German et al., 1998c C.R. German, E.T. Baker, C.A. Mevel, K. Tamaki and FUJI Scientific Team, Hydrothermal activity along the South West Indian Ridge, Nature 395 (1998), pp. 490-493.

German and Lin, 2004 C.R. German and J. Lin, The thermal structure of the oceanic crust, ridge-spreading and hydrothermal circulation: how well do we understand their inter-connections?, Geophys. Monogr. (AGU) 148 (2004), pp. 1-18.

German and Von Damm, 2004 C.R. German and K.L. Von Damm, Hydrothermal Processes, Treatise Geochem. (The Oceans Mar. Geochem.) 6 (2004), pp. 181-222. German et al., 2008 C.R. German, S.A. Bennett, D.P. Connelly, A.J. Evans, B.J. Murton, L.M. Parson, R.D. Prien, E. Ramirez-Llodra, M. Jakuba, T.M. Shank, D.R. Yoerger, E.T. Baker, S.L. Walker and K. Nakamura, Hydrothermal activity on the southern MidAtlantic Ridge: tectonically- and volcanically-controlled venting at 4-5 S, Earth Planet. Sci. Lett. 273 (2008), pp. 332-344.

German et al., 2009 German, C.R., Bowen, A., Coleman, M.L., Huber, J.A., Seewald, J., Van Dover, C., Whitcomb, L.L., Yoerger, D., Connelly, D., Honig, D.L., Jakuba, M., Kinsey, J.C., McDermott, J., Nakamura, K., Sands, C., Smith, J. and Sylva, S., 2009. Hydrothermal Exploration of the Mid-Cayman Spreading Center: Isolated Evolution on Earth's Deepest Mid-Ocean Ridge? EOS, Trans AGU (abstr). OS21B-08.

Ginster et al., 1994 U. Ginster, M.J. Mottl and R.P. Von Herzen, Heat flux from black smokers on the Endeavor and Cleft segments, Juan de Fuca Ridge, J. Geophys. Res. 99 (1994), pp. 4937-4950.

Haymon et al., 1993 R.M. Haymon, D.J. Fornari, K.L. Von Damm, M.D. Lilley, M.R. Perfit, J.M. Edmond, W.C. Shanks, R.A. Lutz, J.M. Grebmeier, S. Carbotte, D. Wright, E. McLaughlin, M. Smith, N. Beedle and E. Olson, Volcanic eruption of the mid-ocean ridge along the EPR crest at $9^{\circ} 45-52^{\prime} \mathrm{N}$ : I. Direct submersible observations of seafloor phenomena associated with an eruption event in April 1991, Earth \& Planet, Sci. Lett. 119 (1993), pp. 85-101.

Hoagland et al., 2009 Hoagland, P., Beaulieu, S., Tivey, M.A., Eggert, R.G., German, C.R., Glowka, L., Lin, J., 2009. Deep Sea Mining of Massive Sulfides. Marine Policy, in press. 
Humphris and Cann, 2000 S.E. Humphris and J.R. Cann, Constraints on the energy and chemical balances of the modern TAG and ancient Cyprus seafloor sulfide deposits, $J$. Geophys. Res. 105 (2000), pp. 28477-28488.

James and Elderfield, 1996 R.H. James and H. Elderfield, Chemistry of ore-forming fluids and mineral formation rates in an active hydrothermal sulfide deposit on the MidAtlantic Ridge, Geology 24 (1996), pp. 1147-1150.

Jean-Baptiste et al., 2004 P. Jean-Baptiste, E. Fourre, J.L. Charlou, C.R. German and J. Radford-Knoery, Helium isotopes at the Rainbow hydrothermal site (Mid-Atlantic Ridge, 36¹4'N), Earth Planet. Sci. Lett. 221 (2004), pp. 325-335.

Kadko and Moore, 1988 D. Kadko and W. Moore, Radiochemical constraints on the crustal residence time of submarine hydrothermal fluids-Endeavour Ridge, Geochim. Cosmochim. Acta 52 (1988), pp. 659-668.

Kadko et al., 1990 D.C. Kadko, N.D. Rosenberg, J.E. Lupton, R.W. Collier and M.D. Lilley, Chemical reaction rates and entrainment within the Endeavor Ridge hydrothermal plume, Earth Planet. Sci. Lett. 99 (1990), pp. 315-335.

Keir et al., 2008 R.S. Keir, O. Schmale, M. Walter, J. Silltenfuss, R. Seifert and M. Rhein, Flux and dispersion of gases from the "Drachenschlund" hydrothermal vent at 8 degrees 18'S, 13 degrees 30'W on the Mid-Atlantic Ridge, Earth Planet. Sci. Lett. 270 (2008), pp. 338-348.

Khripounoff et al., 2001 A. Khripounoff, A. Vangriesheim, P. Crassous, M. Segonzac, A. Colaco, D. Desbruyeres and R. Barthelemy, Particle flux in the Rainbow hydrothermal vent field (Mid-Atlantic Ridge): dynamics, mineral and biological composition, J. Mar. Res. 59 (2001), pp. 633-656.

Langmuir et al., 1997 C. Langmuir, S. Humphris, D. Fornari, C. Van Dover, K. Von Damm, M.K. Tivey, D. Colodner, J.L. Charlou, D. Desonie, C. Wilson, Y. Fouquet, G. Klinkhammer and H. Bougault, Hydrothermal vents near a mantle hot spot: the Lucky Strike vent field at 37 degrees N on the Mid-Atlantic Ridge, Earth Planet. Sci. Lett. 148 (1997), pp. 69-91.

Lupton, 1995 J.E. Lupton, Hydrothermal plumes, near and far field, Geophys. Monogr. (AGU) 91 (1995), pp. 317-346.

Mackey et al., 2002 D.J. Mackey, J.E. O’Sullivan and R.J. Watson, Iron in the western Pacific: a riverine of hydrothermal source for iron in the Equatorial Undercurrent?, Deep Sea Res. I 49 (2002), pp. 877-893.

Massoth et al., 1994 G.J. Massoth, E.T. Baker, J.E. Lupton, R.A. Feely, D.A. Butterfield, K.L. VonDamm, K.K. Roe and G.T. LeBon, Temporal and spatial variability of hydrothermal manganese and iron at Cleft segment, Juan de Fuca Ridge, J. Geophys. Res. 99 (1994), pp. 4905-4923.

Melchert et al., 2008 B. Melchert, C.W. Devey, C.R. German, K.S. Lackschewitz, R. Seifert, M. Walter, C. Ertens, D.R. Yoerger, E.T. Baker, H. Paulick and K. Nakamura, First evidence for high-temperature off-axis venting of deep crustal/mantle heat: the Nibelungen Hydrothermal Field, Southern Mid-Atlantic Ridge, Earth Planet. Sci. Lett. 275 (2008), pp. 61-69.

Mottl, 2003 M.J. Mottl, Partitioning of energy and mass fluxes between mid-ocean ridge axes and flanks at high and low temperature. In: P.E. Halbach, V. Tunnicliffe and J.R. Hein, Editors, Energy and Mass Transfer in Marine Hydrothermal Systems, Dahlem University Press (2003), pp. 271-286. 
Murton et al., 1994 B.J. Murton, G. Klinkhammer, K. Becker, A. Briais, D. Edge, N. Hayward, N. Millard, I. Mitchell, I. Rouse, M. Rudnicki, K. Sayanagi, H. Sloan and L. Parson, Direct evidence for the distribution and occurrence of hydrothermal activity between $27^{\circ} \mathrm{N}-30^{\circ} \mathrm{N}$ on the Mid-Atlantic Ridge, Earth Planet. Sci. Lett. 125 (1994), pp. 119-128.

B.J. Murton, L.J. Redbourn, C.R. German and E.T. Baker, Sources and fluxes of hydrothermal heat, chemicals and biology within a segment of the Mid-Atlantic Ridge, Earth Planet. Sci. Lett. 171 (1999), pp. 301-317.

Nielsen et al., 2006 S.G. Nielsen, M. Rehkämper, D.A.H. Teagle, D.A. Butterfield, J.C. Alt and A.N. Halliday, Hydrothermal fluid fluxes calculated from the isotopic mass balance of thallium in the ocean crust, Earth Planet. Sci. Lett. 251 (2006), pp. 120-133. A.M. Olivarez and R.M. Owen, REE/Fe variations in hydrothermal sedimentsimplications for the REE content of seawater, Geochim. Cosmochim. Acta 53 (1989), pp. 757-762.

M.R. Palmer and J.M. Edmond, The strontium isotope budget of the Modern Ocean, Earth Planet. Sci. Lett. 92 (1989), pp. 11-26.

Parson et al., 2000 L. Parson, E. Gracia, D. Coller, C.R. German and H.D. Needham, Second order segmentation-the relationship between volcanism and tectonism at the MAR, 38N-3540'N, Earth Planet. Sci. Lett. 178 (2000), pp. 231-251.

Petersen et al., 2009 S. Petersen, K. Kuhn, T. Kuhn, N. Augustin, R. Hekinian, L. Franz and C. Borowski, The geological setting of the ultramafic-hosted Logatchev hydrothermal field (14 degrees 45'N, Mid-Atlantic Ridge) and its influence on massive sulfide formation, Lithos 112 (2009), pp. 40-56.

Radford-Knoery et al., 2001 J. Radford-Knoery, C.R. German, J-L. Charlou, J-P. Donval and Y. Fouquet, Distribution and behavior of dissolved hydrogen sulfide in hydrothermal plumes, Limnol. Oceanogr. 46 (2001), pp. 461-464.

Reysenbach et al., 2008 Reysenbach, A.L., Seewald, J., German, C., McCollom, T., Seyfried, W., Ding, K., 2008. Mid-Atlantic Ridge Expedition 2008, R/V Roger Revelle KNOX18RR Cruise Report, 220pp.

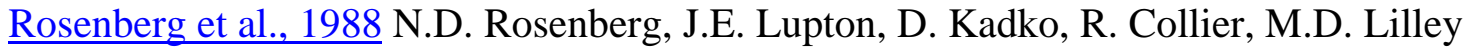
and H. Pak, Estimation of heat and chemical fluxes from a seafloor hydrothermal vent field using radon measurements, Nature 334 (1988), pp. 604-607.

Rudnicki and Elderfield, 1993 M.D. Rudnicki and H. Elderfield, A chemical model of the buoyant and neutrally buoyant plume above the TAG vent field, 26 degrees N, MidAtlantic Ridge, Geochim. Cosmochim. Acta 57 (1993), pp. 2939-2957.

Rudnicki et al., 1995 M.D. Rudnicki, C.R. German, R.E. Kirk, M. Sinha and H. Elderfield, New instrument platform tested at Mid-Atlantic Ridge, EOS, Trans. Am. Geophys. Union 76 (1995), pp. 329-330.

Schultz and Elderfield, 1997 A. Schultz and H. Elderfield, Controls on the physics and chemistry of seafloor hydrothermal circulation, Phil. Trans. R. Soc. Lond. (A) 355 (1997), pp. 387-425.

M.C. Sinha and R.L. Evans, Geophysical constraints upon the thermal regime of the ocean crust, Geophys. Monogr. 148 (2004), pp. 19-62.

Speer and Rona, 1989 K.G. Speer and P.A. Rona, A model of an Atlantic and Pacific hydrothermal plume, J. Geophys. Res. 94 (1989), pp. 6213-6220. 
Tao, C., Lin, J., Guo, S., Chen, Y.J., Wu, G., Han, X., German, C.R., Yoerger, D.R., Zhu, J., Zhou, N., Sun, X., Baker, E.T., DY115-19 Science Party, 2007. First discovery and investigation of a high-temperature hydrothermal vent field on the ultraslow spreading Southwest Indian Ridge, EOS Trans AGU Abstr. T52B-07.

Thurnherr and Richards, 2001 A.M. Thurnherr and K.J. Richards, Hydrography and hightemperature heat flux of the Rainbow hydrothermal site $\left(36^{\circ} 14^{\prime} \mathrm{N}\right.$, Mid-Atlantic Ridge),

J. Geophys. Res. 106 (2001), pp. 9411-9426.

Thurnherr et al., 2002 A.M. Thurnherr, K.J. Richards, C.R. German, G.F. Lane-Serff and K.G. Speer, Flow and Mixing in the Rift Valley of the Mid-Atlantic Ridge, J. Phys. Oc. 32 (2002), pp. 1763-1778.

Tolstoy et al., 2006 M. Tolstoy, J.P. Cowen, E.T. Baker, D.J. Fornari, K.H. Rubin, T.M. Shank, F. Waldhauser, D.R. Bohnenstiehl, D.W. Forsyth, R.C. Holmes, B. Love, M.R. Perfit, R.T. Weekly, S.A. Soule and B. Glazer, A sea-floor spreading event captured by seismometers, Science 314 (2006), pp. 1920-1922.

Toner et al., 2009 B.M. Toner, S.C. Fakra, S.J. Manganini, C.M. Santelli, M.A. Marcus, J.W. Moffett, O. Rouxel, C.R. German and K.J. Edwards, Preservation of iron (II) at hydrothermal vents within carbon-rich matrices, Nature Geosciences (2009) 10.1038/NGEO433.

Veirs et al., 2006 S.R. Veirs, R.E. McDuff and F.R. Stahr, Magnitude and variance of near-bottom horizontal heat flux at the Main Endeavor hydrothermal vent field, Geochem. Geophys. Geosyst. 7 (2006), p. Q02004.

\section{Figures}

Fig.1 Location of the Rainbow hydrothermal field (red star) at $36^{\circ} 14^{\prime} \mathrm{N}$, Mid-Atlantic Ridge. Here, the ridge-axis comprises a series of short $(-50 \mathrm{~km}) 2^{\text {nd }}$ order ridgesegments (coloured green), offset $\sim 20-30 \mathrm{~km}$ by (heavy dashed lines) non-transform discontinuities (Parson et al., 2000). The vent-site lies approximately $200 \mathrm{~km} \mathrm{SW}$ of the Azores (see inset) and is located at the NE corner of the "South AMAR" segment. Also shown (white stars) are other known sites of plume/vent activity along this section of the Mid-Atlantic Ridge including the Lucky Strike and Menez Gwen vents (German et al., 1996a). Yellow color denotes the extent of the Azores hot-spot plateau (water depths $\leq 2000 \mathrm{~m}$ ) flanking the MAR ridge-axis, southwest of the Azores Triple-Junction (Cannat et al., 1999).

Fig.2 Physical characteristics of the dispersing Rainbow hydrothermal plume: a) LADCP (blue) and current-meter (red) flow-velocities at $2100 \mathrm{~m}$, the depth of the nonbuoyant hydrothermal plume. Yellow star represents the site of the Rainbow hydrothermal field; yellow line highlights the Rainbow sill, down-plume from the vent-site, across which all export fluxes are determined. b) LADCP-derived flow velocity between the vent-field and the sill (blue) and near-field particle (Nephels) plume as measured by in situ Light Scattering Sensor (green); c) Scaled particle anomalies (green) and isopycnal temperature anomalies (red) in four selected near-field profiles through the Rainbow non-buoyant hydrothermal plume.

Fig.3 Plot of a) dissolved $\mathrm{CH}_{4}$ concentrations and b) total dissolvable $\mathrm{Mn}$ (TDMn) concentrations in the Rainbow plume versus dissolved ${ }^{3} \mathrm{He}$ concentrations. The 
equations for the least-squares best-fit linear correlations shown in each panel are listed in the Appendix.

Fig.4 Plot of dissolved $\mathrm{CH}_{4}$ concentrations in the Rainbow plume versus total dissolvable $\mathrm{Mn}$ concentrations. The equation for the least-squares best-fit linear correlation shown is listed in the Appendix.

Fig.5 Plot of a) dissolved $\mathrm{CH}_{4}$ concentrations and b) total dissolvable $\mathrm{Mn}$ (TDMn) concentrations in the Rainbow plume versus in situ LSS Voltage Anomalies. The equations for the least-squares best-fit linear correlations shown in each panel are listed in the Appendix.

Fig.6 Plot of total dissolvable Fe (TDFe) concentrations in the Rainbow hydrothermal plume versus total dissolvable Mn (TDMn). The equation for the least-squares best-fit linear correlation shown is listed in the Appendix. 


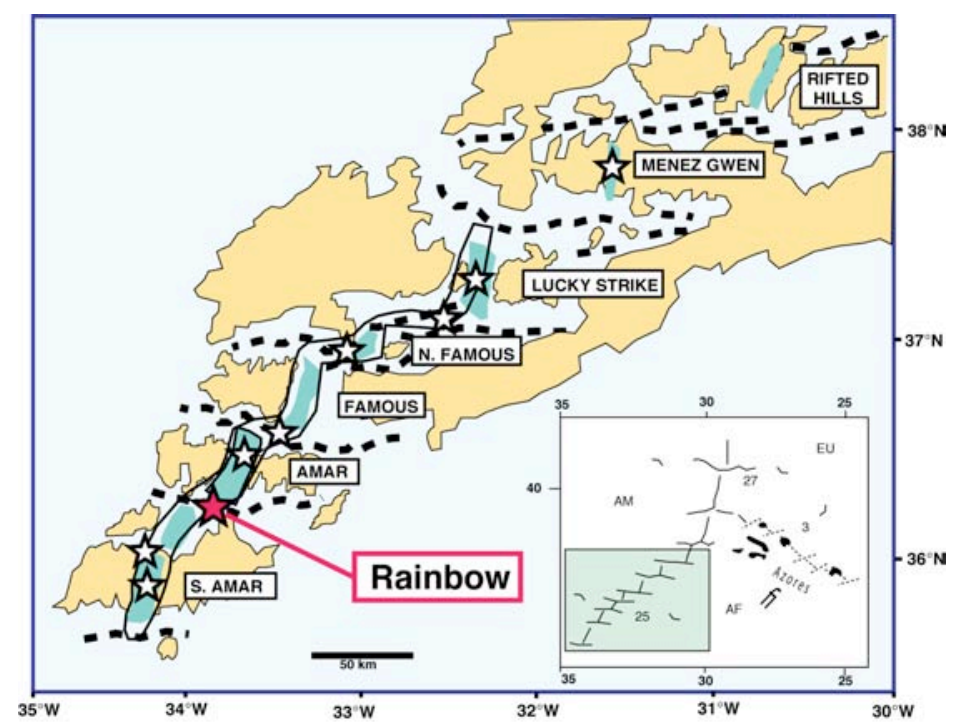

a)

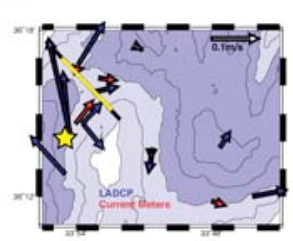

b)

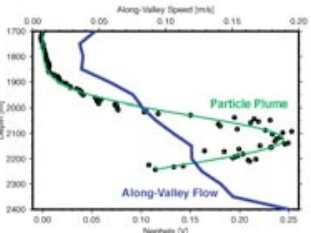

c)

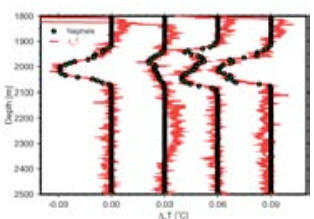



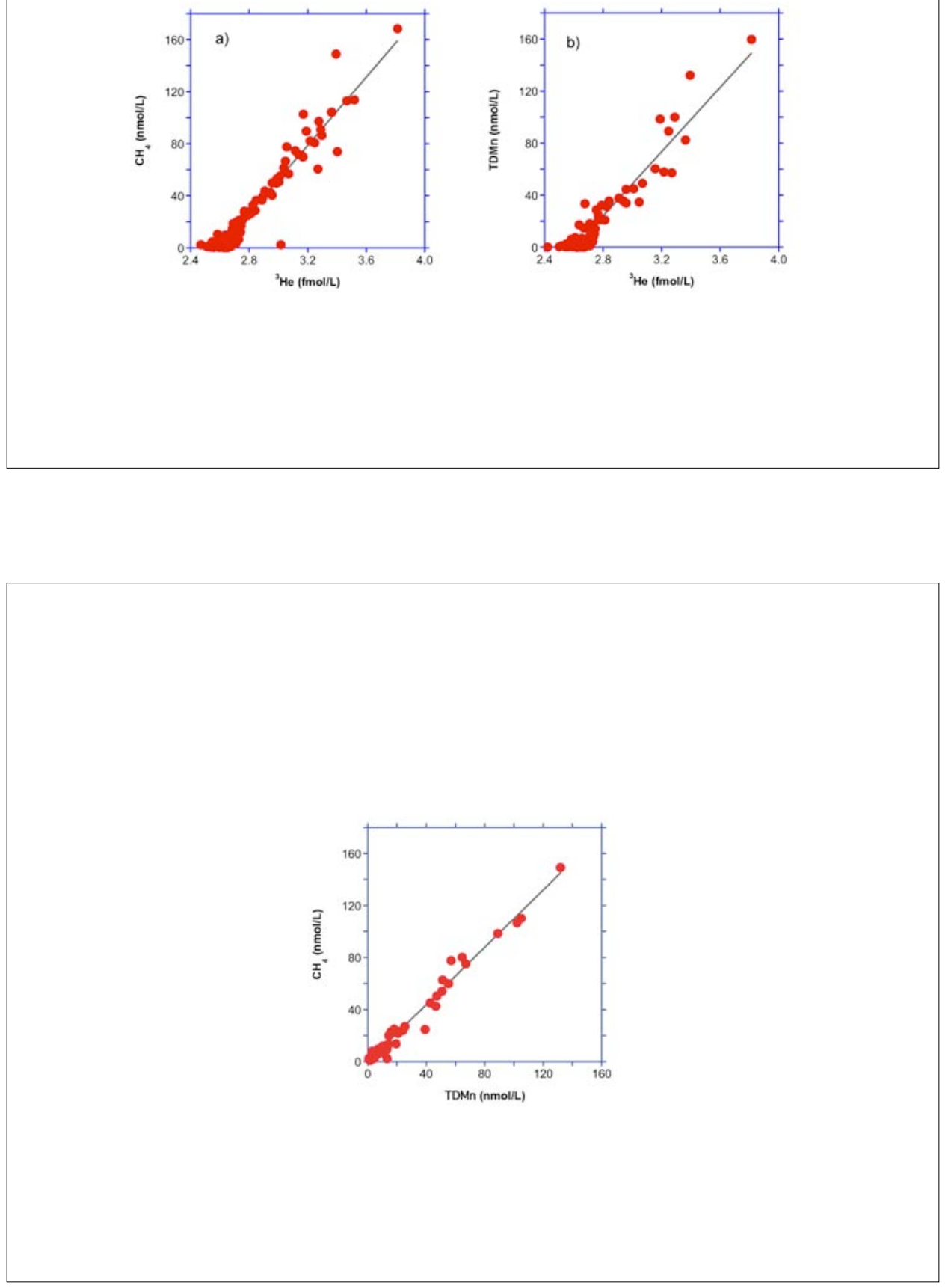

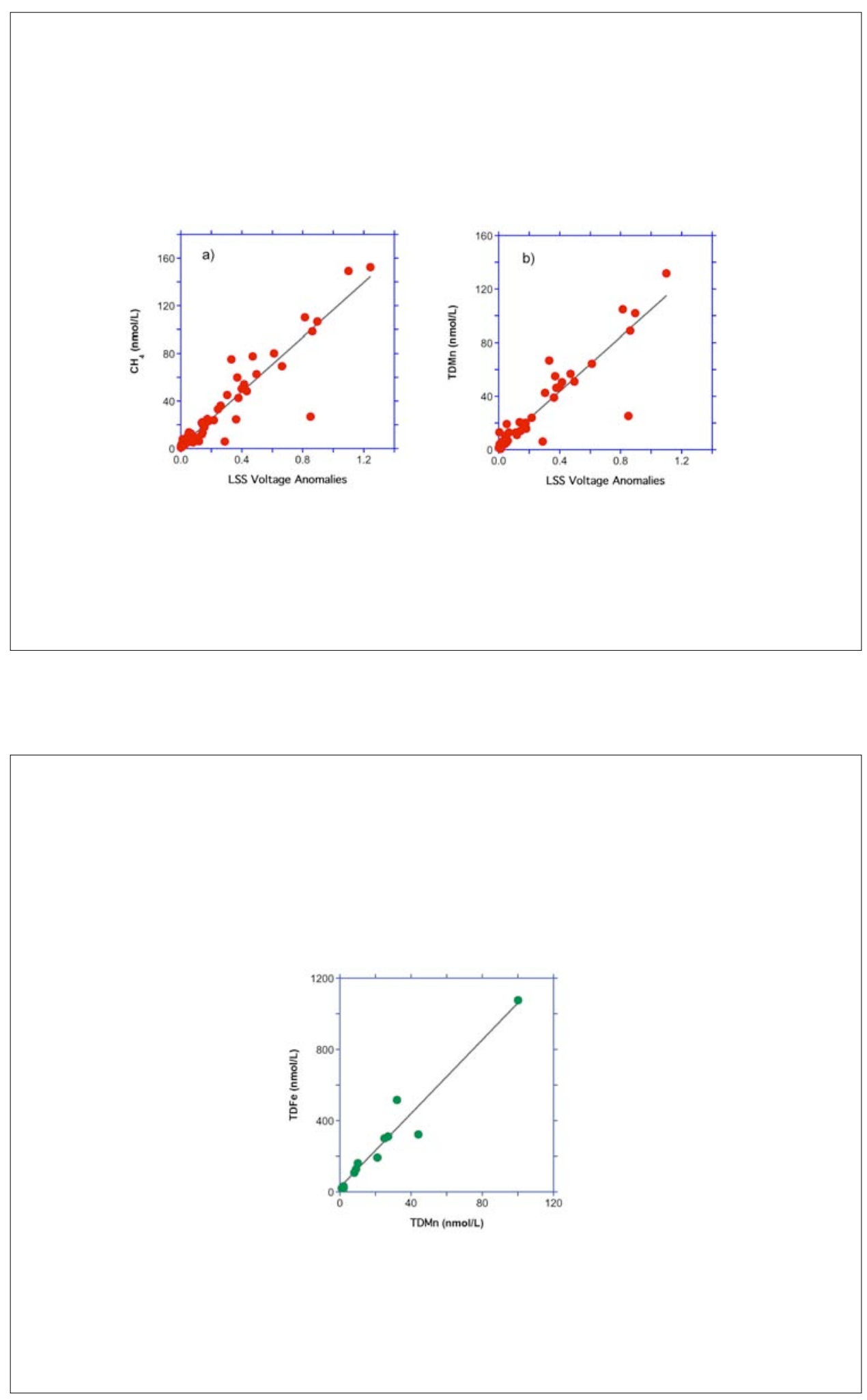
Table 1: Export Fluxes from the Rainbow Vent Site

(Estimated accurate to within factor: $\mathrm{x} 2$ )

$$
\text { Export Flux Units }
$$

Heat $\quad 0,5 \quad(G W)$

\begin{tabular}{|c|c|c|}
\hline Vent-fluid flux [CH4] & 450 & (L.s-1) \\
\hline Vent-fluid flux [Mn] & 400 & (L.s-1) \\
\hline He-3 & $7.6 \times 10 \mathrm{e}-9$ & (mol.s-1) \\
\hline $\mathrm{CH} 4$ & 1,0 & (mol.s-1) \\
\hline $\mathrm{Mn}$ & 0,9 & (mol.s-1) \\
\hline $\mathrm{Fe}$ & 9,6 & (mol.s-1) \\
\hline $\mathrm{Cu}$ & 0,11 & (mol.s-1) \\
\hline $\mathrm{Zn}$ & 0,05 & (mol.s-1) \\
\hline $\mathrm{Cd}$ & $5.2 \times 10 \mathrm{e}-4$ & (mol.s-1) \\
\hline $\mathrm{Ag}$ & $1.1 \times 10 \mathrm{e}-4$ & (mol.s-1) \\
\hline $\mathrm{Pb}$ & $4.5 \times 10 \mathrm{e}-4$ & (mol.s-1) \\
\hline $\mathrm{P}$ & 0,94 & (mol.s-1) \\
\hline $\mathrm{V}$ & 0,036 & (mol.s-1) \\
\hline Co & $2.5 \times 10 \mathrm{e}-3$ & (mol.s-1) \\
\hline $\mathrm{U}$ & $4.9 \times 10 \mathrm{e}-6$ & (mol.s-1) \\
\hline $\mathrm{Y}$ & $2.6 \times 10 \mathrm{e}-4$ & (mol.s-1) \\
\hline $\mathrm{La}$ & $1.2 \times 10 \mathrm{e}-4$ & (mol.s-1) \\
\hline $\mathrm{Ce}$ & $4.9 \times 10 \mathrm{e}-5$ & (mol.s-1) \\
\hline $\operatorname{Pr}$ & $2.4 \times 10 \mathrm{e}-5$ & (mol.s-1) \\
\hline $\mathrm{Nd}$ & $9.6 \times 10 e-5$ & (mol.s-1) \\
\hline
\end{tabular}




$\begin{array}{lll}\mathrm{Yb} & 9.5 \times 10 \mathrm{e}-6 & \text { (mol.s-1) } \\ \mathrm{Lu} & 1.3 \times 10 \mathrm{e}-6 & (\mathrm{~mol} . \mathrm{s}-1)\end{array}$




\section{Correlations used to calculate fluxes reported in Table 1}

\section{Dissolved tracer and LSS voltage correlations}

\begin{tabular}{|cll|}
\hline Element & Y:X Linear Correlations* & $r^{\wedge} 2$ \\
CH4:LSS & {$[\mathrm{CH} 4]=(1.15 \times 10 \mathrm{e}-7 \times[$ LSS $])+2.04 \times 10 \mathrm{e}-9$} & 0,90 \\
TDMn: LSS & {$[$ TDMn $]=(1.02 \times 10 \mathrm{e}-7 \times[$ LSS $])+2.90 \times 10 \mathrm{e}-9$} & 0,86 \\
& & 0,98 \\
CH4: TDMn & {$[\mathrm{CH} 4]=(1.10 \times[$ TDMn $])-2.20 \times 10 \mathrm{e}-10$} & 0,93 \\
& & 0,90 \\
CH4: $\mathrm{He}-3$ & {$[\mathrm{CH} 4]=(1.31 \times 10 \mathrm{e}-8 \times[\mathrm{He}-3])-3.40 \times 10 \mathrm{e}-7$} & 0,94 \\
TDMn:He-3 & {$[$ TDMn $]=(1.23 \times 10 \mathrm{e} 8 \times[\mathrm{He}-3])-3.22 \times 10 \mathrm{e}-7$} & \\
TDFe:TDMn & {$[$ TDFe $]=(10.5 \times[$ TDMn $])+27$} & \\
\hline
\end{tabular}

\section{Particulate Trace Element:Fe correlations}

$\begin{array}{cl}\text { Element } & \text { Element: Fe Linear Correlations } \\ \mathrm{Cu} & {[\mathrm{Cu}]=(1.16 \times 10 \mathrm{e}-2 \times[\mathrm{Fe}])-3.7 \times 10 \mathrm{e}-11} \\ \mathrm{Zn} & {[\mathrm{Zn}]=(5.2 \times 10 \mathrm{e}-3 \times[\mathrm{Fe}])+1.5 \times 10 \mathrm{e}-10} \\ \mathrm{Ag} & {[\mathrm{Ag}]=(1.1 \times 10 \mathrm{e}-5 \times[\mathrm{Fe}])+9.2 \times 10 \mathrm{e}-14} \\ \mathrm{Cd} & {[\mathrm{Cd}]=(5.4 \times 10 \mathrm{e}-5 \times[\mathrm{Fe}])+4.8 \times 10 \mathrm{e}-14} \\ \mathrm{~Pb} & {[\mathrm{~Pb}]=(4.7 \times 10 \mathrm{e}-5 \times[\mathrm{Fe}])+1.1 \times 10 \mathrm{e}-11} \\ \mathrm{P} & {[\mathrm{P}]=(9.8 \times 10 \mathrm{e}-2 \times[\mathrm{Fe}])+4.4 \times 10 \mathrm{e}-10} \\ \mathrm{~V} & {[\mathrm{~V}]=(3.7 \times 10 \mathrm{e}-3 \times[\mathrm{Fe}])+4.8 \times 10 \mathrm{e}-11} \\ \mathrm{Co} & {[\mathrm{Co}]=(2.6 \times 10 \mathrm{e}-4 \times[\mathrm{Fe}])+2.2 \times 10 \mathrm{e}-12} \\ \mathrm{U} & {[\mathrm{U}]=(5.1 \times 10 \mathrm{e}-7 \times[\mathrm{Fe}])+1.7 \times 10 \mathrm{e}-14} \\ \mathrm{Y} & {[\mathrm{Y}]=(2.6 \times 10 \mathrm{e}-5 \times[\mathrm{Fe}])+2.0 \times 10 \mathrm{e}-12} \\ \mathrm{La} & {[\mathrm{La}]=(1.3 \times 10 \mathrm{e}-5 \times[\mathrm{Fe}])+1.3 \times 10 \mathrm{e}-12}\end{array}$




$\begin{array}{|lll|}\mathrm{Ce} & {[\mathrm{Ce}]=(5.1 \times 10 \mathrm{e}-6 \times[\mathrm{Fe}])+2.0 \times 10 \mathrm{e}-3} & 0,65 \\ \mathrm{Pr} & {[\mathrm{Pr}]=(2.5 \times 10 \mathrm{e}-6 \times[\mathrm{Fe}])+3.3 \times 10 \mathrm{e}-4} \\ \mathrm{Nd} & [\mathrm{Nd}]=1.0 \times 10 \mathrm{e}-5 \times[\mathrm{Fe}])+1.3 \times 10 \mathrm{e}-12 & 0,80 \\ \mathrm{Sm} & {[\mathrm{Sm}]=(1.9 \times 10 \mathrm{e}-6 \times[\mathrm{Fe}])+2.5 \times 10 \mathrm{e}-13} & 0,81 \\ \mathrm{Eu} & {[\mathrm{Eu}]=(1.1 \times 10 \mathrm{e}-6 \times[\mathrm{Fe}])+7.1 \times 10 \mathrm{e}-14} & 0,83 \\ \mathrm{Gd} & {[\mathrm{Gd}]=(2.0 \times 10 \mathrm{e}-6 \times[\mathrm{Fe}])+2.1 \times 10 \mathrm{e}-13} & 0,91 \\ \mathrm{~Tb} & {[\mathrm{~Tb}]=(3.4 \times 10 \mathrm{e}-7 \times[\mathrm{Fe}])+3.3 \times 10 \mathrm{e}-14} & 0,86 \\ \mathrm{Dy} & {[\mathrm{Dy}]=(2.1 \times 10 \mathrm{e}-6 \times[\mathrm{Fe}])+2.0 \times 10 \mathrm{e}-13} & 0,89 \\ \mathrm{Ho} & {[\mathrm{Ho}]=(4.5 \times 10 \mathrm{e}-7 \times[\mathrm{Fe}])+3.6 \times 10 \mathrm{e}-14} \\ \mathrm{Er} & {[\mathrm{Er}]=(1.3 \times 10 \mathrm{e}-6 \times[\mathrm{Fe}])+9.7 \times 10 \mathrm{e}-14} & 0,88 \\ \mathrm{Tm} & {[\mathrm{Tm}]=(1.6 \times 10 \mathrm{e}-7 \times[\mathrm{Fe}])+1.2 \times 10 \mathrm{e}-14} & 0,88 \\ \mathrm{Yb} & {[\mathrm{Yb}]=(9.9 \times 10 \mathrm{e}-7 \times[\mathrm{Fe}])+7.5 \times 10 \mathrm{e}-14} & 0,90 \\ \mathrm{Lu} & {[\mathrm{Lu}]=(1.4 \times 10 \mathrm{e}-7 \times[\mathrm{Fe}])+1.0 \times 10 \mathrm{e}-14} & 0,90 \\ \end{array}$

* Data source: German et al. (1998b), Jean-Baptiste et al. (2004)

† Data source: Edmonds \& German (2004) 